\title{
TARIK-MENARIK BAHASA SUNDA DAN BAHASA JAWA DI KABUPATEN PANGANDARAN DALAM TINJAUAN DIALEKTOEKOLINGUISTIK
}

\author{
SUNDANESE AND JAVANESE LANGUAGE ATTRACTIONS IN \\ PANGANDARAN DISTRICT IN DIALECTOEKOLINGUISTIC REVIEW
}

\author{
Wagiati, Duddy Zein
}

Universitas Padjadjaran

Ponsel: 081214152436; Pos-el: wagiati@unpad.ac.id

\begin{abstract}
Abstrak
Penelitian ini mengkaji tarik-menarik bahasa Sunda dan bahasa Jawa di Kabupaten Pangandaran sebagai bentuk primordialisme masyarakat perbatasan Jawa Barat dan Jawa Tengah dalam tinjauan dialektoekolinguistik. Pendekatan yang digunakan dalam penelitian ini terdiri atas dua, yaitu pendekatan teoretis dan pendekatan metodologis. Secara teoretis, pendekatan yang digunakan di dalam penelitian ini adalah pendekatan dialektoekolinguistik. Adapun secara metodologis, penelitian ini menggunakan metode kualitatif-deskriptif. Penyediaan data yang dilakukan dengan metode cakap dan metode simak. Instrumen yang digunakan dalam proses pengumpulan data adalah daftar kosakata (swadesh) yang memuat bahasa dalam sistem kekerabatan yang ada, kata ganti, dan bagian tubuh. Metode analisis yang digunakan dalam penelitian ini adalah metode komparatif-sinkronis. Penelitian ini dilakukan di Kabupaten Pangandaran, Provinsi Jawa Barat - Indonesia dengan memilih lima kecamatan sebagai daerah pengamatan yang ditentukan berdasarkan arah mata angin, yaitu Kecamatan Cimerak, Kecamatan Sidamulih, Kecamatan Kalipucang, Kecamatan Padaherang, dan Kecamatan Pangandaran. Hasil penelitian menunjukkan bahwa: (1) bahasa Sunda dialek Pangandaran memperlihatkan adanya gejala (a) variasi bunyi vokal, (b) variasi bunyi konsonan, (c) aparesis, (d) apokop, dan (e) gejala leksikal; (2) gejala-gejala bahasa yang ada memperlihatkan adanya tarik-menarik antara bahasa Sunda dan bahasa Jawa di Kabupaten Pangandaran sebagai bentuk primordialisme masyarakat perbatasan Jawa Barat dan Jawa Tengah.
\end{abstract}

Kata-kata kunci: bahasa Sunda; bahasa Jawa; Pangandaran; dialektoekolinguistik

\begin{abstract}
This study examines the attraction between Sundanese and Javanese in Pangandaran Regency from a dialectoecolinguistic review. The approach used in this study consists of two, namely a theoretical approach and a methodological approach. Theoretically, the approach used in this study is the dialectoecolinguistic approach. As for the methodology, this study uses qualitative-descriptive methods. The Provision of data is
\end{abstract}


presented through speaking and listening method. The instrument used in the data collection process is a vocabulary list (swadesh) which contains language in the existing kinship system, pronouns, and body parts. The analytical method used in this study is the comparative-synchronous method. This research is conducted in Pangandaran Regency, West Java Province - Indonesia by selecting five districts as observation area determined based on the direction of wind, namely Cimerak District, Sidamulih District, Kalipucang District, Padaherang District, and Pangandaran District. The results show that: (1) Sundanese Pangandaran dialect shows symptoms of (a) variations of vowel sounds, (b) variations of consonant sounds, (c) aparesis, $(d)$ apocopes, and (e) lexical symptoms; (2) the phenomena of the language that show the attractions between Sundanese and Javanese in Pangandaran Regency as a form of primordialism in the border communities of West and Central Java.

Keywords: Sundanese; Javanese; Pangandaran; dialectoecolinguistics

\section{Pendahuluan}

Pesatnya perkembangan bahasa Indonesia menjadi bahasa nasional dan bahasa resmi di negara Indonesia menjadi kondisi yang sangat menggembirakan. Hampir semua generasi terdidik atau terpelajar telah menjadikan bahasa Indonesia sebagai bahasa tutur dalam kehidupan seharihari. Bahasa Indonesia sebagai bahasa nasional telah berhasil menjadi alat komunikasi atau perantara bagi banyak suku bangsa yang hidup dan menyebar di negara kita (Assapari, 2014; Putri, 2017; Wijana, 2018; Yazidi, 2012). Dengan bahasa Indonesia, mereka yang hidup dari latar belakang budaya dan bahasa berbeda pada akhirnya tetap dapat berkomunikasi dengan suku bangsa lainnya. Namun demikian, dalam kondisi yang lain, adanya politik bahasa yang menjadikan bahasa Indonesia sebagai bahasa nasional dipandang lain oleh sebagian masyarakat kita, bahwa kondisi ini dapat menimbulkan kekhawatiran akan terpinggirkannya bahasa daerah sebagai bahasa ibu. Terlebih di tengah arus globalisasi yang menjadikan bahasa Inggris sebagai bahasa internasional. Kondisi ini ikut meramaikan konstelasi lingual dalam penggunaannya. Orang akan semakin melupakan keberadaan bahasa daerah sebagai bahasa pertama. Meskipun pada realitasnya, bahwa sejauh ini belum ada bukti yang menguatkan bahwa pembelajaran dua bahasa atau lebih akan menimbulkan gangguan (Wijana, 2006).

Kebijakan politik bahasa, dalam hal ini peresmian bahasa Indonesia menjadi bahasa nasional, menjadi satu hal yang patut disyukuri. Sebagai bahasa nasional, bahasa Indonesia telah berhasil 
menjadi alat komunikasi dan interaksi antarsuku bangsa yang hidup di negara Indonesia. Perbedaan sosiokultural dan lingual tidak lagi menjadi penghalang komunikasi antarmasyarakat sebab dengan adanya bahasa Indonesia sebagai bahasa nasional, komunikasi antarsuku bangsa akan mudah dilakukan. Ada beberapa kemungkinan yang terjadi apabila bahasa Indonesia tidak dijadikan sebagai bahasa nasional. Pertama, penduduk di daerah dengan bahasa yang berbeda akan berkomunikasi dengan cara mereka masing-masing tanpa keduanya saling mengerti. Situasi ini tentu saja tidak akan menghasilkan praktik komunikasi yang efektif bahkan rentan adanya salah persepsi dan salah komunikasi, alih-alih menyebutnya dengan istilah "kesimpangsiuran komuikasi” (Sedana, 2017).

Kesimpangsiuran komunikasi ini pada masanya nanti akan memunculkan konflik horizontal. Jika kondisi ini terus berlangsung, sampai kapan pun tidak akan pernah ada kesepakatan sosial yang menjadikan bangsa Indonesia sebagai bangsa yang bersatu dalam suatu negara kesatuan. Kedua, memunculkan konsensus sosial untuk memilih dan mengambil salah satu dari kekayaan 413 bahasa daerah (Pusat Bahasa, 2009;
Wahyuni, 2010) sebagai bahasa nasional. Namun demikian, kondisi yang kedua ini akan memunculkan dua risiko besar, yakni munculnya kecemburuan terhadap daerah yang bahasanya terpilih sebagai bahasa nasional dan memunculkan sikap etnosentris pada suku bangsa penutur bahasa yang terpilih menjadi bahasa nasional. Atas dasar itu, pemilihan bahasa Indonesia sebagai bahasa nasional dapat dipandang sebagai kebijakan yang tepat di tengah kondisi bangsa Indonesia yang multikultural.

Kebijakan politik bahasa Indonesia sebagai bahasa nasional pun ternyata masih memunculkan dilema (Sudrama \& Yadnya, 2015). Di satu sisi, kebijakan tersebut bernilai positif karena telah mampu mengurangi potensi disintegrasi antarbangsa di Indonesia. Namun, di sisi yang lain, adanya politik bahasa yang menempatkan bahasa Indonesia sebagai bahasa nasional, sedikit-banyaknya telah memengaruhi penggunaan bahasa-bahasa daerah (Baryadi, 2014; Sutama, 2018). Itulah sebabnya, dewasa ini, keberadaan bahasa-bahasa daerah mulai mengalami tekanan fungsional, seiring dengan politik bahasa tersebut. Atas fakta tersebut di atas, dewasa ini dapat disaksikan bahwa beberapa bahasa 
daerah mulai ditinggalkan oleh penuturnya, meskipun sama-sama berkomunikasi dengan penutur daerah yang sama. Dengan demikian, disadari ataupun tidak, bahasa-bahasa daerah telah mengalami pergeseran bahasa. Jika kondisi ini terus dibiarkan, tidak menutup kemungkinan akan mengarah kepada gejala kepunahan bahasa (language death) (Ibrahim, 2011). Hal ini senada dengan apa yang diungkapkan oleh Mbete bahwa apabila dalam suatu keluarga, praktik berbahasa antara orang tua dengan anaknya --dan sebaliknya-dalam bahasa lokal sudah semakin jarang, apalagi menghilang, kondisi ini merupakan tanda serius akan adanya kematian bahasa (Mbete, 2003).

Namun demikian, di tengah hiruk-pikuk kecemasan orang-orang akan lunturnya loyalitas berbahasa daerah, naluri pemertahanan bahasa sebenarnya sudah dimiliki secara alami oleh penuturnya. Tarik-menarik kosakata bahasa satu dengan bahasa lainnya yang sering bersinggungan merupakan bentuk nyata upaya pemertahanan bahasa. Tarik-menarik ini tanpa disadari telah memberikan pengaruh pada bahasa lawan dan bahasa penutur sendiri. Pengaruh itu bisa diadaptasi secara langsung tanpa melalui perubahan bunyi atau melalui perubahan bunyi. Oleh sebab itu, dapat dikatakan bahwa saling keterpengaruhan itu merupakan bentuk eksistensi dari masing-masing bahasa.

Dalam perspektif dialektologis, terlihatnya keterpengaruhan antarbahasa yang saling bersinggungan sangat memungkinkan terjadi. Hal tersebut dapat terjadi karena satu bahasa dapat memengaruhi bahasa lainnya. Di sisi yang lain, bahasa 'pribumi' memiliki imunitas untuk bertahan dari pengaruh bahasa luar dan pada masanya nanti dapat terjadi pula adanya kompromi dari kedua bahasa yang saling berpengaruh tersebut.

Kondisi demikian terjadi pada dialek bahasa Sunda di Pangandaran, yang mengalami kontak dengan bahasa Jawa. Kedua bahasa tersebut saling berpengaruh satu sama lain sehingga dapat ditemukan glos-glos yang memiliki realisasi yang sama dan etimon yang sama. Kondisi ini pada masanya nanti akan memunculkan kesimpangsiuran tentang status bahasa di wilayah tersebut. Kesimpangsiuran tersebut akan terlihat jelas apabila dilakukan kalkulasi dialektometri untuk menentukan status bahasa dan dialek di wilayah tersebut. Sampai saat ini, memang, batasan mengenai bahasa dan 
dialek masih menjadi isu perdebatan yang berkepanjangan di antara sesama dialektolog. Hal ini disebabkan oleh bahwa menentukan kriteria yang tepat, akurat, dan cermat untuk dapat membedakan antara bahasa dan dialek menjadi salah satu isu teoretis yang rumit dalam kajian linguistik.

Pangandaran merupakan salah satu kabupaten di Provinsi Jawa Barat dengan tingkat kompleksitas penduduknya yang cukup tinggi. Kompleksitas tersebut salah satunya disebabkan oleh letak geografis Pangandaran yang berbatasan dengan Kabupaten Cilacap Provinsi Jawa Tengah. Kondisi ini menjadikan Pangandaran sebagai salah satu daerah enclave bahasa yang di dalamnya memungkinkan adanya persinggungan dua bahasa atau lebih. Persinggungan antarbahasa akan memunculkan dinamika lingual yang kompleks pula. Kabupaten Pangandaran mayoritas berpenduduk suku Sunda. Namun demikian, karena salah satu kebijakan politik masa orde baru, yakni transmigrasi dan pemerataan penduduk di wilayah Indonesia, khususnya Jawa, menjadikan banyaknya penduduk suku Jawa yang juga tinggal dan menetap di Pangandaran. Transmigrasi ini juga sedikit-banyaknya akan berpengaruh terhadap dinamika sosiokultural dan lingual yang ada di Pangandaran.

Bahasa Sunda dan bahasa Jawa, secara status kebahasaan, merupakan dua bahasa yang berkerabat, yaitu masuk rumpun Austronesia atau Nusantara (Mulyana, 1975). Relasi di antara bahasa sekerabat ternyata tidak sama dekat antara satu bahasa dengan bahasa lainnya, ada yang lebih dekat atau lebih jauh (Blust, 1977). Blust mengelompokkan bahasa sekerabat berdasarkan jauh dekatnya hubungan yang dinamakan subgrouping. Telah banyak penelitian tentang subgrouping bahasa Nusantara, seperti penelitian Imam Syafii dan Abd. Syukur Ibrahim (Syafii \& Ibrahim, 2019), Emily A. Gasser (Gasser, 2015), La Ino (Ino, 2015), Iqbal Nurul Azhar (Azhar, 2010), Budasi (Budasi, 2012), Yundi Fitrah dan Rengki Afria (Fitrah \& Afria, 2017), dan Suryata (Suryata, 1998). Suryata (1998) secara khusus mengelompokkan bahasa Sunda dan bahasa Jawa sebagai bahasa sekerabat yang memiliki relasi yang cukup dekat.

Penelitian ini bertujuan menguak sedikit-banyaknya tentang tarik-menarik antara bahasa Sunda dialek Pangandaran dan bahasa Jawa yang mengalami 
persinggungan di Kabupaten

Pangandaran. Relasi bahasa tersebut dapat dilihat dari adanya saling pengaruh di antara keduanya dengan pola-pola lingual tertentu dan tingkat pemertahanan tertentu pula. Di lain sisi, penelitian ini juga dapat menguak pola migrasi bahasa Jawa yang tersebar di daerah Pangandaran. Oleh sebab itu, pertanyaan penelitian yang dijawab pada penelitian ini adalah (1) bagaimanakah pola variasi bahasa Sunda Dialek Pangandaran, dan (2) bagaimana tarikmenarik bahasa Sunda dan bahasa Jawa di Kabupaten Pangandaran.

Hasil penelitian ini bermanfaat bagi pengembangan teori linguistik, khususnya dialektologi dan linguistik komparatif, dan secara praktis memberikan masukan bagi pengambilan kebijakan dalam rangka pemertahanan bahasa dan pengembangan bahasa, khususnya di Pangandaran dan Jawa Barat.

\section{Metode Penelitian}

Pendekatan yang digunakan dalam penelitian ini terdiri atas dua, yaitu pendekatan teoretis dan pendekatan metodologis. Secara teoretis, pendekatan yang digunakan di dalam penelitian ini adalah ekolinguistik dialektal. Ekolonguistik itu sendiri dapat dipahami sebagai gabungan kajian antara linguistik dan ekologi (Mbete, 2015; Subiyanto, 2013; Tarigan, 2016). Kajian tersebut mengelaborasikan dua disiplin ilmu untuk mengungkap fakta ilmiah dalam serangkaian kajian ilmiah. Kegiatan elaborasi dua disiplin ilmu dewasa ini mengalami perkembangan yang relatif signifikan karena disiplin ilmu apa saja dapat melengkapi satu sama lain untuk mengungkap dan menerangkan fakta-fakta ilmiah yang tidak mengenal batasan-batasan tertentu (Mahsun, 2010). Pada penelitian ini, digunakan terminologi dialektoekolinguisik sebagai bentuk kajian multidisiplin antara dialektologi dan ekolinguistik.

Adapun secara metodologis, penelitian ini menggunakan metode kualitatif-deskriptif. Secara kualitatif, data yang diteliti dan hasil analisisnya diperoleh dari rekaman, pengamatan, wawancara, atau bahan tertulis dan data ini tidak berbentuk angka (Djajasudarma, 2010; Gunawan, 2013; Nugrahani, 2014; Sugiono, 2011; Yusuf, 2014). Sementera itu, pendekatan deskriptif mendasarkan pada fakta yang secara empiris dan penutur-penuturnya, sehingga hasilnya berupa perian bahasa seperti apa adanya. Penggunaan metode 
deskriptif ini senada dengan apa yang dijelaskan Sudaryanto bahwa data yang didapatkan adalah hasil pengamatan penulis tanpa menilai salah atau benar suatu data (Sudaryanto, 2015).

Tahapan penelitian ini dibagi ke dalam tiga tahapan, yaitu tahap penyediaan data, tahap analisis data, dan tahap penyajian hasil analisis data.

Pelaksanaan penelitian diawali dengan penyediaan data yang dilakukan dengan metode cakap dan metode simak (Sudaryanto, 2015). Pada tahap penyediaan data, langkah pertama yang dilaksanakan adalah menentukan daerah yang akan dijadikan sebagai lokasi penelitian ini. Setelah itu, tahapan yang harus dilaksanakan adalah menyediakan data dengan menggunakan metode cakap, yaitu metode pengumpulan data lingual dengan melakukan percakapan antara peneliti dengan penutur sebagai narasumber. Pengumpulan data ini pun dilakukan dengan beberapa teknik, di antaranya adalah teknik cakapan terarah, bertanya langsung, bertanya tidak langsung, memancing jawaban, dan bertanya untuk memperoleh jawaban berganda.

Instrumen yang digunakan dalam proses pengumpulan data adalah daftar kosakata (swadesh) yang di dalamnya memuat beberapa bagian yang akan ditanyakan, yaitu bahasa dalam sistem kekerabatan yang ada, kata ganti, dan bagian tubuh. Berikut alat pengumpul data (instrumen) penelitian yang digunakan berupa:

a) Data informan yang ditujukan kepada informan untuk mengungkapkan identitas informan, mulai dari tempat lahir, lamanya tinggal, dan mobilitas informan;

b) Data isian desa yang ditujukan kepada kepala desa serta penduduknya;

c) Daftar tanyaan berupa daftar kosakata yang ditujukan kepada informan untuk mengungkapkan data kosakata.

Selanjutnya, dalam metode cakap, peneliti langsung mewawancarai informan (teknik cakap semuka) dan menyimak berian mereka dengan mencatat dan merekam (teknik rekam dan catat) berian mereka pada daftar tanya ataupun cerita-cerita spontan mereka yang berhasil dipancing oleh peneliti. Rekaman ini digunakan sebagai pengecek data pada saat dijumpai kebimbangan mengenai data yang ada (yang telah dicatat). Apabila data yang dibutuhkan sudah didapatkan, tahap selanjutnya adalah bagaimana data 
tersebut diolah dan dianalisis. Sebanyak 20 orang dijadikan sebagai informan pada penelitian ini

Daftar tanya yang digunakan di dalam penelitian ini berupa 300 kosakata dasar swadesh yang dimodifikasi sesuai dengan keperluan dan tujuan penelitian. Daftar tanya ini terdiri atas tiga kelompok pertanyaan dan terbagi dalam 12 bagian, yakni kosakata yang mengandung makna berikut: sistem kekerabatan, kata ganti, bagian-bagian tubuh, bagian-bagian rumah, alat-alat, keadaan dan bagian alam, tumbuhan dan buah-buahan, hewan/binatang, makanan/minuman, sifat/keadaan, ekspresi abstrak dan kata kerja, serta kata tanya, kata sambung, dan lain-lain. Kosakata yang digunakan adalah kosakata bahasa Sunda sehari-hari.

Metode analisis yang digunakan dalam penelitian ini adalah metode komparatif-sinkronis. Maksudnya adalah data yang diperoleh dari berbagai desa yang diteliti dibandingkan dengan sesamanya dan dibandingkan dengan bahasa Sunda daerah lain.

Penelitian ini dilakukan di Kabupaten Pangandaran dengan memilih lima kecamatan sebagai daerah pengamatan yang ditentukan berdasarkan arah mata angin. Di setiap kecamatan ditentukan empat desa yang dipilih berdasarkan arah mata angin juga. Daerah-daerah yang diambil sebagai tempat penelitian adalah Kecamatan Cimerak (Desa Legok Jawa, Desa Kertaharja, Desa Masawah, dan Desa Sindangsari); Kecamatan Padaherang (Desa Wuluh, Desa Paledah, Desa Maruyungsari, dan Desa Sindangwangi); Kecamatan Kalipucang (Desa Tunggilis, Desa Bagolo, Desa Cibuluh, dan Desa Emplak); Kecamatan Sidamulih (Desa Cikembulan, Desa Pajaten, Desa Sidamulih, dan Desa Sukaresik); dan Kecamatan Pangandaran (Desa Wonoharjo, Desa Sidomulyo, Desa Sukaharjo, dan Desa Pananjung).

\section{Pembahasan}

Posisi geografis masyarakat etnis Sunda di Kabupaten Pangandaran, Jawa Barat sebagai penutur asli bahasa Sunda sangat strategis. Karena berada di enclave bahasa, penutur bahasa Sunda di Pangandaran memungkinkan bersinggungan dengan penutur bahasa lainnya, khususnya bahasa Jawa. Daerah Pangandaran menjadi salah satu daerah perbatasan antarprovinsi, yakni Provinsi Jawa Barat dan Provinsi Jawa Tengah. Setiap daerah perbatasan kerap kali menjadi bahasa peralihan, tidak hanya 
dalam aspek administrative, melainkan juga dalam aspek bahasa dan budaya. Saling pengaruh antarbahasa dan antarbudaya menjadi hal yang lumrah terjadi di daerah perbatasan. Bahasa Sunda Dialek Pangandaran berinteraksi dengan bahasa Jawa di Cilaccap, Jawa Tengah. Kantong-kantong bahasa Jawa juga banyak ditemukan di daerah Pangandaran.

Jejak-jejak pengaruh kejawaan jelas terlihat di Pangandaran. Salah satunya terlihat dari nama-nama tempat yang ada di daerah tersebut yang identik dengan aturan fonologi bahasa Jawa, seperti Kedung Wuluh, Tunggilis, Bagolo, Wonoharjo, Sidomulyo, Sukoharjo, dan sebagainya. Kondisi ini mempertegas satu hal bahwa wilayah administratif tidak dapat membatasi di mana sebuah bahasa mesti dituturkan.

Karena kajian ini dilakukan dengan menggunakan pendekatan dialektoekolinguistik, data-data lingual yang telah dijaring menggunakan daftar kosakata (swadesh) tidak akan dijadikan sebagai data kajian seluruhnya. Data tersebut disaring kembali dengan hanya menjadikan kosakata yang masuk pada dimensi biologis sesuai dengan pendekatan ekolinguistik yang akan dijadikan sebagai data kajian, yaitu kosakata-kosakata yang memiliki relasi antara kehidupan manusia dengan tanaman, hewan, alam, bumi, laut, dsb. Oleh karena itu, dari keseluruhan data yang ada, hanya didapat 57 kosakta yang akan dikaji pada penelitin ini. Keseluruhan data tersebut akan dikaji berdasarkan analisis dialektal untuk melihat adanya tarik-menarik antara bahasa Sunda dialek Pangandaran dengan bahasa Jawa yang ada di Kabupaten Pangandaran. Data-data tersebut adalah sebagai berikut.

Tabel 1

Keseluruhan Data Penelitian

\begin{tabular}{|l|l|l|l|}
\hline No. & Gloss & Bentuk Realisasi & $\begin{array}{l}\text { Daerah Pengamatan } \\
\text { (Kecamatan) }\end{array}$ \\
\hline 1 & Hitam & hidöy & 1,2 \\
& & $\begin{array}{l}\text { idöy } \\
\text { irəy }\end{array}$ & 3 \\
& & abu? & 4,5 \\
\hline 2 & Abu & ləbu? & 3 \\
& & awu? & $1,2,4$ \\
& & lintah & 5 \\
\hline 3 & lintah & & 3,4 \\
\hline
\end{tabular}




\begin{tabular}{|c|c|c|c|}
\hline & & lentah & $1,2,5$ \\
\hline 4 & bintang & $\begin{array}{l}\text { bintay } \\
\text { bentay }\end{array}$ & $\begin{array}{l}2,3,4 \\
1,5\end{array}$ \\
\hline 5 & burung & $\begin{array}{l}\text { manuk } \\
\text { manu? }\end{array}$ & $\begin{array}{l}1,2,3 \\
4,5\end{array}$ \\
\hline 6 & dinding tembok & $\begin{array}{l}\text { tembok } \\
\text { tembo? }\end{array}$ & $\begin{array}{l}1,2 \\
3,4,5\end{array}$ \\
\hline 7 & busuk & $\begin{array}{l}\text { buruk } \\
\text { borok }\end{array}$ & $\begin{array}{l}1,3 \\
2,4,5 \\
\end{array}$ \\
\hline 8 & Api & $\begin{array}{l}\text { sönö? } \\
\text { gəni? }\end{array}$ & $\begin{array}{l}1,2 \\
3,4,5\end{array}$ \\
\hline 9 & tanah & $\begin{array}{l}\text { tanöh } \\
\text { ləmah }\end{array}$ & $\begin{array}{l}1,4 \\
2,3,5\end{array}$ \\
\hline 10 & besar & gəd $\varepsilon$ & $1,2,3,4,5$ \\
\hline 11 & bulan & $\begin{array}{l}\text { Bulan } \\
\text { Wulan }\end{array}$ & $\begin{array}{l}2,3,4 \\
1,5\end{array}$ \\
\hline 12 & hidup & $\begin{array}{l}\text { hirup } \\
\text { irup } \\
\text { urip }\end{array}$ & $\begin{array}{l}1,2 \\
3 \\
4,5\end{array}$ \\
\hline 13 & Hati & $\begin{array}{l}\text { hat }{ }^{?} \\
\text { ati? }\end{array}$ & $\begin{array}{l}5 \\
1,2,3,4\end{array}$ \\
\hline 14 & hujan & $\begin{array}{l}\text { hujan } \\
\text { ujan } \\
\text { udan }\end{array}$ & $\begin{array}{l}1,2 \\
3 \\
4,5\end{array}$ \\
\hline 15 & benih & $\begin{array}{l}\text { binih } \\
\text { winih }\end{array}$ & $\begin{array}{l}2,3,4 \\
1,5\end{array}$ \\
\hline 16 & Bulu & $\begin{array}{l}\text { bulu? } \\
\text { wulu? }\end{array}$ & $\begin{array}{l}2,3,4 \\
1,5\end{array}$ \\
\hline 17 & darah & Gotih & $1,2,3,4,5$ \\
\hline 18 & $\begin{array}{l}\text { daun kelapa } \\
\text { kering }\end{array}$ & $\begin{array}{l}\text { baralak } \\
\text { blarak }\end{array}$ & $\begin{array}{l}2,3,4 \\
1,5\end{array}$ \\
\hline 19 & kepala & $\begin{array}{l}\text { sira? } \\
\text { Sirah }\end{array}$ & $\begin{array}{l}4,5 \\
1,2,3\end{array}$ \\
\hline 20 & perut & $\begin{array}{l}\text { bötöy } \\
\text { wötön }\end{array}$ & $\begin{array}{l}1,2,3 \\
4,5\end{array}$ \\
\hline 21 & Lidah & $\begin{array}{l}\text { leta? } \\
\text { letah } \\
\text { litah }\end{array}$ & $\begin{array}{l}5 \\
1,3 \\
2,4 \\
\end{array}$ \\
\hline 22 & dinding tembok & $\begin{array}{l}\text { tembok } \\
\text { t\&mbo? }\end{array}$ & $\begin{array}{l}1,2 \\
3,4,5\end{array}$ \\
\hline 23 & punggung & $\begin{array}{l}\text { tojoy } \\
\text { gəgər }\end{array}$ & $\begin{array}{l}1,2,3 \\
4,5\end{array}$ \\
\hline 24 & Lutut & $\begin{array}{l}\text { dəykul } \\
\text { tu? ur }\end{array}$ & $\begin{array}{l}5 \\
1,2,3,4\end{array}$ \\
\hline 25 & Ibu & $\begin{array}{l}\text { piyun } \\
\text { mama? }\end{array}$ & $\begin{array}{l}5 \\
1,2,3,4\end{array}$ \\
\hline
\end{tabular}




\begin{tabular}{|c|c|c|c|}
\hline 26 & kuning & $\begin{array}{l}\text { konen } \\
\text { kunin }\end{array}$ & $\begin{array}{l}1,2,3 \\
4,5\end{array}$ \\
\hline 27 & Kutu & $\begin{array}{l}\text { kutu? } \\
\text { tuma? }\end{array}$ & $\begin{array}{l}1,2,3 \\
4,5 \\
\end{array}$ \\
\hline 28 & pusar & $\begin{array}{l}\text { bujal } \\
\text { pusər } \\
\text { pusar }\end{array}$ & $\begin{array}{l}1,3 \\
2,4 \\
5\end{array}$ \\
\hline 29 & Tali & tali? $^{?}$ & $1,2,3,4,5$ \\
\hline 30 & tulang & $\begin{array}{l}\text { tulan } \\
\text { baluy }\end{array}$ & $\begin{array}{l}2,3,4 \\
1,5\end{array}$ \\
\hline 31 & matahari & $\begin{array}{l}\text { panonpo\& } \\
\text { srəy\&y } \varepsilon^{?}\end{array}$ & $\begin{array}{l}1,3 \\
2,4,5 \\
\end{array}$ \\
\hline 32 & Pasir & $\begin{array}{l}\text { pasir } \\
\text { wədi? }\end{array}$ & $\begin{array}{l}1,2,3,4 \\
5\end{array}$ \\
\hline 33 & tanah & $\begin{array}{l}\text { tanöh } \\
\text { ləmah }\end{array}$ & $\begin{array}{l}1,4 \\
2,3,5\end{array}$ \\
\hline 34 & akar & $\begin{array}{l}\text { akar } \\
\text { oyod }\end{array}$ & $\begin{array}{l}1,2,3 \\
4,5\end{array}$ \\
\hline 35 & rumput & $\begin{array}{l}\text { jukut } \\
\text { sukət }\end{array}$ & $\begin{array}{l}1,2,3,4 \\
5\end{array}$ \\
\hline 36 & Ikan & $\begin{array}{l}\text { lauk } \\
\text { iwak }\end{array}$ & $\begin{array}{l}1,2,3,4 \\
5\end{array}$ \\
\hline 37 & kepiting & $\begin{array}{l}\text { köyöp } \\
\text { yuyu? }\end{array}$ & $\begin{array}{l}1,4 \\
2,3,5\end{array}$ \\
\hline 38 & kambing & $\begin{array}{l}\text { əmbe? } \\
\text { Wədus }\end{array}$ & $\begin{array}{l}1,3,4 \\
2,5\end{array}$ \\
\hline 39 & Kera & $\begin{array}{l}\text { mońst } \\
\text { kətek }\end{array}$ & $\begin{array}{l}1,3,4 \\
2,5\end{array}$ \\
\hline 40 & banyak & $\begin{array}{l}\text { loba } \\
\text { sö’ör } \\
\text { sikeh }\end{array}$ & $\begin{array}{l}1,3 \\
2,4 \\
5\end{array}$ \\
\hline 41 & basah & $\begin{array}{l}\text { tələs } \\
\text { basöh }\end{array}$ & $\begin{array}{l}3,4,5 \\
1,2\end{array}$ \\
\hline 42 & bengkak & $\begin{array}{l}\text { baröh } \\
\text { apuh }\end{array}$ & $\begin{array}{l}1,2,3 \\
4,5 \\
\end{array}$ \\
\hline 43 & Berat & $\begin{array}{l}\text { börat } \\
\text { abot }\end{array}$ & $\begin{array}{l}3,4 \\
1,2,5\end{array}$ \\
\hline 44 & buruk & $\begin{array}{l}\text { gorsy } \\
\text { clek }\end{array}$ & $\begin{array}{l}1,3,5 \\
2,4\end{array}$ \\
\hline 45 & gemuk & $\begin{array}{l}\text { montok } \\
\text { ləmu? }\end{array}$ & $\begin{array}{l}1,2,3 \\
4,5 \\
\end{array}$ \\
\hline 46 & Jauh & $\begin{array}{l}\text { adoh } \\
\text { jauh }\end{array}$ & $\begin{array}{l}5 \\
1,2,3,4\end{array}$ \\
\hline 47 & Kecil & $\begin{array}{l}\text { lötik } \\
\text { cilik }\end{array}$ & $\begin{array}{l}2,3,4 \\
1,5\end{array}$ \\
\hline 48 & lebar & $\mathrm{amba}^{?}$ & $1,2,3,4,5$ \\
\hline 49 & licin & lö?ör & 1,4 \\
\hline
\end{tabular}




\begin{tabular}{|l|l|l|l|}
\hline & & luń? & $2,3,5$ \\
\hline 50 & panjang & $\begin{array}{l}\text { panją } \\
\text { dawa? }\end{array}$ & $\begin{array}{l}1,2,3 \\
4,5\end{array}$ \\
\hline 51 & pendek & $\begin{array}{l}\text { pondok } \\
\text { cilək }\end{array}$ & 1,4 \\
& & hörin & $2,3,5$ \\
\hline 52 & supək & $1,2,3,4$ \\
& & sököt & 5 \\
\hline 53 & Tajam & landəp & 1,2 \\
& & Dapuy & $3,4,5$ \\
\hline 54 & apung & Mabur & $1,2,3$ \\
& & Dupin & 4,5 \\
\hline 55 & dengar & kruyu? & $1,2,3$ \\
& & Dantəm & 4,5 \\
\hline 56 & lempar & Baledog & $3,4,5$ \\
& & Moton & 1,2 \\
\hline 57 & potong & Nugəl & $1,2,3,4$ \\
& & & 5 \\
\hline
\end{tabular}

\subsection{Variasi Bahasa Sunda Dialek Pangandaran}

Beberapa gejala bahasa yang ditemukan di lapangan adalah gejala sinonim dan homonim. Sinonim atau sinonimi adalah hubungan semantik yang menyatakan adanya kesamaan makna antara satu satuan ujaran dengan satuan ujaran lainnya (Chaer, 2012). Sementara itu, homonim atau homonimi adalah dua buah kata atau satuan ujaran yang bentuknya "kebetulan" sama; maknanya tentu saja berbeda, karena masing-masing merupakan kata atau bentuk ujaran yang berlainan (Chaer, 2012).

Variasi bunyi bahasa yang banyak ditemukan berupa sinonim, yaitu kata-kata yang bunyinya berbeda, tetapi maknanya sama. Perbedaan bunyi timbul akibat adanya gejala-gejala seperti variasi bunyi baik vokal maupun konsonan, protesis (penambahan fonem di awal), epentesis (penambahan fonem di tengah), paragog (penambahan fonem di akhir), aparesis (penghilangan fonem di awal), sinkop (penghilangan fonem di tengah), dan apokop (penghilangan fonem di akhir).

Gejala variasi bunyi bahasa pertama yang terlihat pada bahasa Sunda dialek Pangandaran adalah variasi bunyi vokal. Data-data yang memperlihatkan adanya variasi bunyi vokal adalah: lintah yang direalisasikan dengan kata lintah $(3,4)$ dan lentah $(1,2,5)$; bintang yang direalisasikan dengan kata bintay $(2,3$, 4) dan bentan (1, 5); busuk yang 
direalisasikan dengan kata buruk $(1,3)$ dan borok (2, 4, 5); hidup yang direalisasikan dengan kata hirup $(1,2)$, Irup (3), dan urip (4, 5); hati yang direalisasikan dengan kata hat $\varepsilon^{?}$ (5) dan ati $^{?}(1,2,3,4)$; lidah yang direalisasikan dengan kata leta? (5), letah (1, 3), dan litah (2, 4); kuning yang direalisasikan dengan kata konen $(1,2,3)$ dan kunin $(4$, 5); serta pusar yang direalisasikan dengan kata bujal $(1,3)$, pusər $(2,4)$, dan pusar (5). Untuk lebih jelasnya hal itu dapat dilihat pada tabel berikut ini.

Tabel 2

Gejala Variasi Vokal pada Bahasa Sunda Dialek Pangandaran

\begin{tabular}{|c|c|c|c|}
\hline No. & Gloss & Bentuk realisasi (DP) & Keterangan \\
\hline 1 & lintah & $\begin{array}{l}\text { lintah }(3,4) \\
\text { lentah }(1,2,5)\end{array}$ & $\begin{array}{l}\text { Fonem } / \mathrm{i} / \text { dan } / \mathcal{E} / \text { saling } \\
\text { bervariasi }\end{array}$ \\
\hline 2 & Bintang & $\begin{array}{l}\text { bintan }(2,3,4) \\
\text { bentan }(1,5)\end{array}$ & $\begin{array}{l}\text { Fonem } / \mathrm{i} / \text { dan } / \varepsilon / \text { saling } \\
\text { bervariasi }\end{array}$ \\
\hline 3 & Busuk & $\begin{array}{l}\text { buruk }(1,3) \\
\text { borok }(2,4,5)\end{array}$ & $\begin{array}{l}\text { Fonem } / \mathrm{u} / \mathrm{dan} / \mathrm{o} / \text { saling } \\
\text { bervariasi }\end{array}$ \\
\hline 4 & Hidup & $\begin{array}{l}\text { hirup }(1,2) \\
\text { irup }(3) \\
\text { urip }(4,5)\end{array}$ & $\begin{array}{l}\text { Fonem /i/ dan /u/ saling } \\
\text { bervaraisi }\end{array}$ \\
\hline 5 & hati & $\begin{array}{l}\text { hate? }(5) \\
\text { ati? }(1,2,3,4)\end{array}$ & $\begin{array}{l}\text { Fonem } / \varepsilon / \text { dan } / \mathrm{i} / \text { saling } \\
\text { bervariasi }\end{array}$ \\
\hline 6 & lidah & $\begin{array}{l}\text { leta? }(5) \\
\text { letah }(1,3) \\
\text { litah }(2,4)\end{array}$ & $\begin{array}{l}\text { Fonem } / \varepsilon / \text { dan } / \mathrm{i} / \text { saling } \\
\text { bervariasi }\end{array}$ \\
\hline 7 & kuning & $\begin{array}{l}\text { konsy }(1,2,3) \\
\text { kuniy }(4,5)\end{array}$ & $\begin{array}{l}\text { Fonem } / \varepsilon / \text { dan } / \mathrm{i} / \text { saling } \\
\text { bervariasi }\end{array}$ \\
\hline 8 & pusar & $\begin{array}{l}\text { bujal }(1,3) \\
\text { pusər }(2,4) \\
\text { pusar }(5)\end{array}$ & $\begin{array}{l}\text { Fonem } / \varepsilon / \text { dan } / \mathrm{a} / \text { saling } \\
\text { bervariasi }\end{array}$ \\
\hline
\end{tabular}

Selain adanya gejala variasi vokal, bahasa Sunda dialek Pangandaran juga memperlihatkan adanya variasi konsonan. Data-data yang memperlihatkan adanya gejala variasi konsonal adalah: $a b u$ yang direalisasikan dengan kata abu? (3), ləbu? $(1,2,4)$, dan awu? (5); burung yang direalisasikan dengan kata manuk $(1,2,3)$ dan manu? $(4, \quad 5) ; \quad$ dinding tembok yang direalisasikan dengan kata tembok $(1,2)$ dan tembo? (3, 4, 5); bulan yang direalisasikan dengan kata bulan $(2,3,4)$ dan wulan (1, 5); hujan yang direalisaikan dengan kata hujan $(1,2)$, ujan (3), dan udan $(4,5)$; benih yang direalisasikan dengan kata binih $(2,3,4)$ dan winih (1, 5); daun kelapa kering yang direalisasikan dengan kata baralak $(2,3,4)$ dan blarak $(1,5)$; serta perut 
yang direalisasikan dengan kata bötöy jelasnya hal itu dapat dilihat pada tabel $(1,2,3)$ dan wötöy $(4,5)$. Untuk lebih berikut ini.

Tabel 3

Gejala Variasi Konsonan pada Bahasa Sunda Dialek Pangandaran

\begin{tabular}{|c|c|c|c|}
\hline No. & Gloss & $\begin{array}{l}\text { Bentuk Realisasi } \\
\text { (DP) }\end{array}$ & Keterangan \\
\hline 1 & Abu & $\begin{array}{l}\text { abu? (3) } \\
\text { ləbu? }(1,2,4) \\
\text { awu? (5) }\end{array}$ & $\begin{array}{l}\text { Fonem /b/ dan /w/ } \\
\text { saling bervariasi }\end{array}$ \\
\hline 2 & burung & $\begin{array}{l}\text { manuk }(1,2,3) \\
\text { manu? }(4,5)\end{array}$ & $\begin{array}{l}\text { Fonem /k/ dan /?/ saling } \\
\text { bervariasi }\end{array}$ \\
\hline 3 & diding tembok & $\begin{array}{l}\text { tembok }(1,2) \\
\text { tembo? }(3,4,5)\end{array}$ & $\begin{array}{l}\text { Fonem / } / \mathrm{k} / \text { dan /?/ saling } \\
\text { bervariasi }\end{array}$ \\
\hline 4 & bulan & $\begin{array}{l}\text { bulan }(2,3,4) \\
\text { wulan }(1,5)\end{array}$ & $\begin{array}{l}\text { Fonem /b/ dan /w/ } \\
\text { saling bervariasi }\end{array}$ \\
\hline 5 & hujan & $\begin{array}{l}\text { hujan }(1,2) \\
\text { ujan }(3) \\
\text { udan }(4,5)\end{array}$ & $\begin{array}{l}\text { Fonem } / \mathrm{j} / \mathrm{dan} \\
\text { saling bervariasi }\end{array}$ \\
\hline 6 & benih & $\begin{array}{l}\text { binih }(2,3,4) \\
\text { winih }(1,5)\end{array}$ & $\begin{array}{l}\text { Fonem /b/ dan /w/ } \\
\text { saling bervariasi }\end{array}$ \\
\hline 7 & $\begin{array}{l}\text { daun } \\
\text { kering }\end{array}$ & $\begin{array}{l}\text { baralak }(2,3,4) \\
\text { blarak }(1,5)\end{array}$ & $\begin{array}{l}\text { Fonem } / \mathrm{r} / \text { dan } / \mathrm{l} / \mathrm{saling} \\
\text { bervariasi }\end{array}$ \\
\hline 8 & perut & $\begin{array}{l}\text { bötöy }(1,2,3) \\
\text { wötöy }(4,5)\end{array}$ & $\begin{array}{l}\text { Fonem /b/ dan /w/ } \\
\text { saling bervariasi }\end{array}$ \\
\hline
\end{tabular}

Selanjutnya, gejala bahasa irup (3), dan urip (4, 5); hujan yang lainnya yang muncul pada bahasa Sunda dialek Pangandaran adalah aparesis (penghilangan fonem di awal) dan apokop (penghilangan fonem di akhir). direalisasikan dengan kata hujan $(1,2)$, ujan (3), dan udan (4, 5); hati yang direalisasikan dengan kata hat $\varepsilon^{?}$ (5) dan ati? (1, 2, 3, 4); serta kepala yang Data-data tersebut adalah: hitam yang direalisasikan dengan kata sira? $(4,5)$ direalisasikan dengan kata hidöy $(1,2)$, idöy (3), dan irəy $(4,5)$; hidup yang direalisasikan dengan kata hirup $(1,2)$, dan sirah $(1,2,3)$. Untuk lebih jelasnya hal tersebut dapat dilihat pada tabel berikut ini. 


\section{Tabel 4}

Gejala Aparesis dan Apokop pada Bahasa Sunda dialek Pangandaran

\begin{tabular}{|c|c|c|c|}
\hline No. & Gloss & $\begin{array}{l}\text { Bentuk Realisasi } \\
\text { (DP) }\end{array}$ & Keterangan \\
\hline 1 & hitam & $\begin{array}{l}\text { hidön }(1,2) \\
\text { idön }(3) \\
\text { irəy }(4,5)\end{array}$ & aparesis \\
\hline 2 & Hidup & $\begin{array}{l}\text { hirup }(1,2) \\
\text { irup }(3) \\
\text { urip }(4,5)\end{array}$ & Aparesis \\
\hline 3 & hujan & $\begin{array}{l}\text { hujan }(1,2) \\
\text { ujan }(3) \\
\text { udan }(4,5)\end{array}$ & Aparesis \\
\hline 4 & hati & $\begin{array}{l}\text { hate? }(5) \\
\text { ati? }(1,2,3,4)\end{array}$ & Apokop \\
\hline 5 & kepala & $\begin{array}{l}\operatorname{sira}^{?}(4,5) \\
\operatorname{sirah}(1,2,3)\end{array}$ & Apokop \\
\hline
\end{tabular}

Selain gejala fonologis, terdapat gejala lain yang muncul pada bahasa Sunda dialek Pangandaran sebagai pengaruh dari bahasa Jawa, yaitu gejala leksikal. Kemunculan gejala ini pada bahasa Sunda dialek Pangandaran relatif banyak. Penyerapan utuh leksikon bahasa Jawa ke dalam bahasa Sunda dialek Pangandaran terjadi pada beberapa kelas kata, yaitu nomina, verba, dan ajektiva. Berikut ini adalah beberapa kosakata dalam bahasa Sunda dialek Pangandaran yang mengalami pengaruh dari bahasa Jawa berupa penyerapan utuh leksikon bahasa Jawa ke dalam bahasa Sunda dialek Pangandaran. 
Tabel 5

Kosakata Serapan dari Bahasa Jawa ke dalam Bahasa Sunda Dialek Pangandaran

\begin{tabular}{|c|c|c|c|c|}
\hline No. & Gloss & Bentuk Realisasi & $\begin{array}{c}\text { Daerah } \\
\text { Pengamatan }\end{array}$ & Keterangan \\
\hline 1 & Mulut & $\begin{array}{l}\text { Bibir } \\
\text { biwir } \\
\text { lambe? }\end{array}$ & $\begin{array}{l}1 \\
2 \\
3,4,5\end{array}$ & nomina \\
\hline 2 & Punggung & $\begin{array}{l}\text { Toyon } \\
\text { Gəgər }\end{array}$ & $\begin{array}{l}1,2,3 \\
4,5\end{array}$ & nomina \\
\hline 3 & Tulang & $\begin{array}{l}\text { Baluy } \\
\text { Tulay }\end{array}$ & $\begin{array}{l}3,4,5 \\
1,2\end{array}$ & nomina \\
\hline 4 & Lutut & $\begin{array}{l}\text { Dəykul } \\
\text { tu? ur }\end{array}$ & $\begin{array}{l}5 \\
1,2,3,4\end{array}$ & nomina \\
\hline 5 & Ibu & $\begin{array}{l}\text { Piyun } \\
\text { mama? }\end{array}$ & $\begin{array}{l}5 \\
1,2,3,4\end{array}$ & nomina \\
\hline 6 & Api & $\begin{array}{l}\text { sönö? } \\
\text { gəni? }\end{array}$ & $\begin{array}{l}1,2 \\
3,4,5\end{array}$ & nomina \\
\hline 7 & Matahari & $\begin{array}{l}\text { panonpos } \\
\text { srəy\&y } \varepsilon^{?}\end{array}$ & $\begin{array}{l}1,3 \\
2,4,5 \\
\end{array}$ & nomina \\
\hline 8 & Pasir & $\begin{array}{l}\text { Pasir } \\
\text { wədi? }\end{array}$ & $\begin{array}{l}1,2,3,4 \\
5\end{array}$ & nomina \\
\hline 9 & Tanah & $\begin{array}{l}\text { Tanöh } \\
\text { Ləmah }\end{array}$ & $\begin{array}{l}1,4 \\
2,3,5\end{array}$ & nomina \\
\hline 10 & akar & $\begin{array}{l}\text { akar } \\
\text { oyod }\end{array}$ & $\begin{array}{l}1,2,3 \\
4,5\end{array}$ & nomina \\
\hline 11 & Rumput & $\begin{array}{l}\text { jukut } \\
\text { sukət }\end{array}$ & $\begin{array}{l}1,2,3,4 \\
5\end{array}$ & nomina \\
\hline 12 & Ikan & $\begin{array}{l}\text { lauk } \\
\text { iwak }\end{array}$ & $\begin{array}{l}1,2,3,4 \\
5\end{array}$ & nomina \\
\hline 13 & Kepiting & $\begin{array}{l}\text { Köyöp } \\
\text { yuyu? }\end{array}$ & $\begin{array}{l}1,4 \\
2,3,5\end{array}$ & Nomina \\
\hline 14 & kambing & $\begin{array}{l}\text { əmbe } \\
\text { Wədus }\end{array}$ & $\begin{array}{l}1,3,4 \\
2,5\end{array}$ & Nomina \\
\hline 15 & Kera & $\begin{array}{l}\text { Mońct } \\
\text { Kətek }\end{array}$ & $\begin{array}{l}1,3,4 \\
2,5\end{array}$ & Nomina \\
\hline 16 & Banyak & $\begin{array}{l}\text { Loba } \\
\text { sö?ör } \\
\text { sikeh }\end{array}$ & $\begin{array}{l}1,3 \\
2,4 \\
5 \\
\end{array}$ & Ajektiva \\
\hline 17 & Basah & $\begin{array}{l}\text { Tələs } \\
\text { Basöh }\end{array}$ & $\begin{array}{l}3,4,5 \\
1,2\end{array}$ & Ajektiva \\
\hline 18 & Bengkak & $\begin{array}{l}\text { Baröh } \\
\text { Apuh }\end{array}$ & $\begin{array}{l}1,2,3 \\
4,5\end{array}$ & Ajektiva \\
\hline 19 & Berat & $\begin{array}{l}\text { Börat } \\
\text { Abot }\end{array}$ & $\begin{array}{l}3,4 \\
1,2,5\end{array}$ & Ajektiva \\
\hline
\end{tabular}




\begin{tabular}{|c|c|c|c|c|}
\hline 20 & Buruk & $\begin{array}{l}\text { Goren } \\
\text { Elek }\end{array}$ & $\begin{array}{l}1,3,5 \\
2,4\end{array}$ & Ajektiva \\
\hline 21 & Gemuk & $\begin{array}{l}\text { Montok } \\
\text { ləmu? }\end{array}$ & $\begin{array}{l}1,2,3 \\
4,5\end{array}$ & Ajektiva \\
\hline 22 & Jauh & $\begin{array}{l}\text { Adoh } \\
\text { Jauh }\end{array}$ & $\begin{array}{l}5 \\
1,2,3,4\end{array}$ & Ajektiva \\
\hline 23 & Kecil & $\begin{array}{l}\text { Lötik } \\
\text { cilik }\end{array}$ & $\begin{array}{l}2,3,4 \\
1,5\end{array}$ & Ajektiva \\
\hline 24 & lebar & amba? & $1,2,3,4,5$ & Ajektiva \\
\hline 25 & Licin & $\begin{array}{l}\text { lö?ör } \\
\text { luńu? }\end{array}$ & $\begin{array}{l}1,4 \\
2,3,5\end{array}$ & Ajektiva \\
\hline 26 & Panjang & $\begin{array}{l}\text { panjay } \\
\text { dawa? }\end{array}$ & $\begin{array}{l}1,2,3 \\
4,5\end{array}$ & Ajektiva \\
\hline 27 & Pendek & $\begin{array}{l}\text { pondok } \\
\text { cilək }\end{array}$ & $\begin{array}{l}1,4 \\
2,3,5\end{array}$ & Ajektiva \\
\hline 28 & sempit & $\begin{array}{l}\text { hörin } \\
\text { rupək }\end{array}$ & $\begin{array}{l}1,2,3,4 \\
5\end{array}$ & Ajektiva \\
\hline 29 & Tajam & $\begin{array}{l}\text { sököt } \\
\text { landəp }\end{array}$ & $\begin{array}{l}1,2 \\
3,4,5\end{array}$ & Ajektiva \\
\hline 30 & apung & $\begin{array}{l}\text { yapun } \\
\text { mabur }\end{array}$ & $\begin{array}{l}1,2,3 \\
4,5\end{array}$ & Verba \\
\hline 31 & dengar & $\begin{array}{l}\text { yupin } \\
\text { kruyu? }\end{array}$ & $\begin{array}{l}1,2,3 \\
4,5\end{array}$ & Verba \\
\hline 32 & lempar & $\begin{array}{l}\text { yantom } \\
\text { baledog }\end{array}$ & $\begin{array}{l}3,4,5 \\
1,2\end{array}$ & Verba \\
\hline 33 & Potong & $\begin{array}{l}\text { moton } \\
\text { nugal }\end{array}$ & $\begin{array}{l}1,2,3,4 \\
5\end{array}$ & Verba \\
\hline
\end{tabular}


3.2 Tarik-Menarik Bahasa Sunda dan Bahasa Jawa di Kabupaten Pangandaran sebagai bentuk Variasi Kebahasaan Masyarakat Perbatasan Jawa Barat dan Jawa Tengah

Suku Jawa selalu identik dengan migrasi dan perpindahan wilayah. Suku Jawa dengan berbagai subetnisnya terpencar di berbagai wilayah, termasuk di sebagian wilayah Jawa Barat yang notabene mayoritas berbahasa Sunda. Dari segi geografis, Pangandaran dianggap sebagai wilayah yang memiliki daya tarik alam, kesuburan tanah, ketersediaan lapangan pekerjaan, dan kondisi kultural masyarakat yang terbuka dengan keberadaan etnis lain, telah menjadi daya tarik masyarakat dari luar daerah untuk bermigrasi ke Pangandaran. Faktor geografis inilah yang menjadi salah satu faktor pemicu adanya perpindahan etnis Jawa ke Pangandaran yang pada masanya nanti berpengaruh juga terhadap kondisi bahasa Sunda dialek Pangandaran. Faktor geografis ini tidak bisa dilepaskan dari faktor demografis; keberlimpahan kekayaan alam Pangandaran telah menyebabkan adanya lonjakan migrasi penduduk etnis Jawa ke daerah Pangandaran. Migrasi etnis Jawa ini membawa pengaruh kultural, termasuk pengaruh bahasa Jawa terhadap bahasa Sunda dialek Pangandaran.

Suku Jawa kerap kali menghuni satu wilayah dengan bercocok tanam. Kadang-kadang juga berpindah-pindah mengikuti aliran sungai dan daerah yang subur. Pada umumnya, etnis Jawa berpindah ke Pangandaran untuk bercocok tanam demi kebutuhan pangan khususnya karbohidratnya sambil berburu untuk memenuhi kebutuhan proteinnya. Aktivitas bercocok tanam dan berburu tersebut, sedikit-banyaknya berpengaruh terhadap kondisi lingual bahasa Sunda di Pangandaran. Kosakata-kosakata bahasa Sunda dialek Pangandaran yang banyak terpengaruh bahasa Jawa sering ditemukan dalam istilah ekologi hutan atau lingkungan alam, khususnya hutan hujan tropis di Pangandaran.

Berbicara tentang transmigrasi di Indonesia, tentu terbayang dan tidak lepas dari peran sosok Presiden RI ke-2, yakni Soeharto. Pada masa orde baru, transmigrasi menjadi salah satu program andalan Soeharto yang tertuang dalam Pembangunan Lima Tahun (Pelita) 1 sampai 6. Program transmigrasi era Soeharto masuk dalam generasi transmigrasi orde baru. Sebelumnya, pada tahun 1905 s.d. 1942 dikenal dengan istilah kolonialisasi. Kemudian Jepang 
masuk menjajah Indonesia, kemudian istilahnya berubah menjadi kerja rodi (romusha). Pascakemerdekaan hingga 1966, pada masa orde lama, barulah ada transmigrasi, tetapi keberlangsungannya tidak berjalan mulus. Ketika Soeharto menjadi Presiden RI, Pelita I sampai VI dicanangkan pada 1969, dan pada saat itulah transmigrasi mulai digencarkan.

Program transmigrasi di era Soeharto ini sering dikenal dengan istilah bedol desa atau sejuta gambut. Kebijakan politik ini sedikit-banyaknya berdampak terhadap kehidupan sosio-kultural di tengah-tengah masyarakat Indonesia. Banyak lahan kosong yang digarap oleh para imigran dan kemudian lahan-lahan tersebut, seiring dengan perkembangan zaman dan generasi, berubah menjadi wilayah-wilayah layak huni mulai dari tingkat kampung, desa, hingga kabupaten.

Pangandaran juga tidak lepas dari kebijakan politik Soeharto. Di wilayah ini, pada masa itu, masih banyak lahan kosong yang mesti digarap. Hingga akhirnya banyak pula masyarakat dari etnis Jawa yang berpindah ke sebagian wilayah Pangandaran dan menetap hingga masa generasi sekarang. Kebijakan politik ini juga berdampak pada dinamika sosiokultural yang ada di Pangandaran, khususnya pada aspek lingual di wilayah tersebut.

\section{Penutup}

Dari pemaparan di atas, dapat disimpulkan beberapa hal sebagai berikut.

Pertama, beberapa gejala bahasa yang muncul dari bahasa Sunda dialek Pangandaran dilihat dari aspek dialektologis adalah (1) variasi bunyi vokal, (2) variasi bunyi konsonan, (3) aparesis, (4) apokop, dan gejala leksikal.

Kedua, kosakata-kosakata bahasa Sunda Dialek Pangandaran yang banyak terpengaruh bahasa Jawa sering ditemukan dalam istilah ekologi hutan atau lingkungan alam, khususnya hutan hujan tropis di Pangandaran.

\section{Daftar Pustaka}

Assapari, M. M. (2014). Eksistensi Bahasa Indonesia sebagai Bahasa Nasional dan Perkembangannya di Era Globalisasi. PRASI, 9 (18), 29-37.

https://doi.org/10.23887/prasi.v9i18. 8943.g5776

Azhar, I. N. (2010). Jejak Protobahasa Austronesia pada Bahasa Madura (Kajian Bandingan Historis terhadap Retensi dan Inovasi Fonem Protobahasa Austronesia pada Bahasa Madura). Jurnal METALINGUA, 8 (1), 1--29.

Baryadi, I. P. (2014). Pengembangan 
"Dwibahasawan yang Seimbang" untuk Mempertahankan BahasaBahasa Daerah di Indonesia. Sintesis: Jurnal Ilmiah Kebudayaan, $8(2), 60--68$.

Blust, R. (1977). The Proto Austronesian Pronouns and Austronesian Subgrouping. A Preliminary Report, Rijkuniversiteit.

Budasi, I. G. (2012). Phonological Evidences Which Separate and Unite Mamboro Language from Proto Wanokaka-Anakalang in Sumba Group of Languages. A Biannual Publication on The Study of Language and Literature, 14 (2), 67 -74 .

Chaer, A. (2012). Linguistik Umum: Edisi Revisi. Rineka Cipta.

Djajasudarma, F. (2010). Metode Linguistik: Ancangan Metode Penelitian dan Kajian. Rafika Aditama.

Fitrah, Y., \& Afria, R. (2017). Kekerabatan Etnis-Etnis Melayu, Batak, Sunda, Bugis, dan Jawa di Provinsi Jambi: Sebuah Kajian Linguistik Historis Komparatif. Jurnal Ilmu Humaniora, 1 (2), 204-218.

Gasser, E. A. (2015). The Development of Verbal Infixation in Cenderawasih Bay. In I. W. Arka, M. Donohue, B. Evans, N. Evans, S. Greenhill, G. Hyslop, D. Nash, B. Palmer, A. Pawley, M. Ross, P. Sidwell, \& J. Simson (Eds.), Language Change in Austronesian languages. Asia-Pacific Linguistics College of Asia and the Pacific The Australian National University.
Gunawan, I. (2013). Metode Penelitian Kualitatif. Bumi Aksara.

Ibrahim, G. A. (2011). Bahasa Terancam Punah: Fakta, Sebab-Musabab, Gejala, dan Strategi Perawatannya. Linguistik Indonesia, 29 (1), 35--52.

Ino, L. (2015). Pemanfaatan Linguistik Historis Komparatif dalam Pemetaan Bahasa-Bahasa Nusantara. RETORIKA: Jurnal Ilmu Bahasa, 1 (2), 351--365.

Mahsun. (2010). Genolinguistik: Kolaborasi Linguistik dengan Genetika dalam Pengelompokan Bahasa dan Populasi Penuturnya. Pustaka Pelajar.

Mbete, A. M. (2003). Bahasa dan Budaya Lokal Minorita, Asal-Muasal, Ancaman Kepunahan dan Ancangan Pemberdayaan dalam Kerangka Pola Ilmiah Pokok Kebudayaan Universitas Udayana. Pidato Pengukuhan Jabatan Guru Besar Tetap Dalam Bidang Linguistik Pada Fakultas Sastra Universitas Udayana.

Mbete, A. M. (2015). Pembelajaran Bahasa Berbasis Lingkungan: Perspektif Ekolinguistik. RETORIKA: Jurnal Ilmu Bahasa, 1 (2), 352--364.

Mulyana, S. (1975). Asal Bangsa dan Bahasa Nusantara. Balai Pustaka.

Nugrahani, F. (2014). Metode Penelitian Kualitatif. Cakra Books.

Putri, N. P. (2017). Eksistensi Bahasa Indonesia pada Generasi Milenial. Widyabastra: Jurnal Ilmiah Pembelajaran Bahasa Dan Sastra Indonesia, 5 (1), 45--49. 
Sedana, G. (2017). Komunikasi Simpang Siur dalam Pembangunan Masyarakat: Kasus pada Media Masa. Jurnal Kajian Ilmu Komunikasi, 15 (2), 50-61.

Subiyanto, A. (2013). Ekolinguistik: Model Analisis dan Penerapannya. Humanika, 18 https://doi.org/10.14710/humanika.1 8.2 .

Sudaryanto. (2015). Metode dan Aneka Teknik Analisis Bahasa. Sanata Dharma University Press.

Sudrama, K., \& Yadnya, I. B. P. (2015). Dilema Multilingualisme Dan Implikasinya Terhadap Perencanaan Bahasa. RETORIKA: Jurnal Ilmu Bahasa, 1 (1), 94--107.

Sugiono. (2011). Metode Penelitian Kuantitatif Kualitatif dan $R \& D$. Alfabeta.

Suryata, P. (1998). Subgrouping dan Migrasi Sembilan Bahasa di Indonesia: Kajian Linguistik Komparatif. Jurnal Iptek Dan Humaniora, 3 (2), 111--125.

Sutama, P. (2018). Politik Bahasa, Regulasi, dan Eksistensi Bahasa Lokal. Seminar Internasional APBL, $1-8$.

Syafii, I., \& Ibrahim, A. S. (2019). Leksikostatistika Lima Bahasa Nusantara: Bahawa Jawa, Bahasa Madura, Bahasa Sunda, Bahasa Bali, dan Bahasa Indonesia. BASINDO: Jurnal Kajian Bahasa, Sastra Indonesia, Dan Pembelajarannya, 3 (1), 85--93.

Tarigan, B. (2016). Kebertahanan dan
Ketergeseran Leksikon Flora Bahasa Karo: Kajian Ekolinguistik. Universitas Sumatera Utara.

Wahyuni, S. (2010). Tarik-Menarik Bahasa Jawa Dialek Banyumas dan Bahasa Sunda di Perbatasan Jawa Tengah-Jawa Barat Bagian Selatan sebagai Sikap Pemertahanan Bahasa oleh Penutur. Undip Semarang.

Wijana, D. P. (2018). Pemertahanan dan Pengembangan Bahasa Indonesia (Indonesian Language Maintenance And Development). Widyaparwa: Jurnal Ilmiah Kebahasaan Dan Kesastraan, 46 (1), 91--98.

Wijana, I. D. P. (2006). Sosiolinguistik: Kajian Teori dan Analisis. Pustaka Pelajar.

Yazidi, A. (2012). Bahasa Indonesia sebagai Identitas Nasional Bangsa Indonesia. Jurnal Bahasa Dan Sastra, 2 (2), 163--177.

Yusuf, M. (2014). Metode Penelitian Kuantitatif, Kualitatif \& Penelitian Gabungan. Kencana. 